\title{
Essential oils of aromatic Egyptian plants repel nymphs of the tick Ixodes ricinus (Acari: Ixodidae)
}

\author{
Hesham R. El-Seedi ${ }^{1,2,3,4} \cdot$ Muhammad Azeem ${ }^{3,5}$ • \\ Nasr S. Khalil ${ }^{3,6}$ - Hanem H. Sakr ${ }^{7}$ - Shaden A. M. Khalifa ${ }^{8}$. \\ Khalijah Awang ${ }^{2} \cdot$ Aamer Saeed $^{9} \cdot$ Mohamed A. Farag ${ }^{10}$ • \\ Mohamed F. AlAjmi ${ }^{11} \cdot$ Katinka Pålsson $^{3}$ - Anna-Karin Borg-Karlson ${ }^{3}$
}

Received: 28 October 2016/Accepted: 2 April 2017/Published online: 1 September 2017

(C) The Author(s) 2017. This article is an open access publication

\begin{abstract}
Due to the role of Ixodes ricinus (L.) (Acari: Ixodidae) in the transmission of many serious pathogens, personal protection against bites of this tick is essential. In the present study the essential oils from 11 aromatic Egyptian plants were isolated and their repellent activity against $I$. ricinus nymphs was evaluated Three oils (i.e. Conyza dioscoridis L., Artemisia herba-alba Asso and Calendula officinalis L.) elicited high repellent activity in vitro of $94,84.2$ and $82 \%$, respectively. The most active essential oil (C. dioscoridis) was applied in the field at a concentration of $6.5 \mu \mathrm{g} / \mathrm{cm}^{2}$ and elicited a
\end{abstract}

Hesham R. El-Seedi

hesham.el-seedi@fkog.uu.se

$\bowtie$ Anna-Karin Borg-Karlson

akbk@kth.se

1 Division of Pharmacognosy, Department of Medicinal Chemistry, Biomedical Centre, Uppsala University, Box 574, 75123 Uppsala, Sweden

2 Department of Chemistry, Faculty of Science, University of Malaya, 50603 Kuala Lumpur, Malaysia

3 Ecological Chemistry Group, Department of Chemistry, School of Chemical Science and Engineering, KTH, Royal Institute of Technology, Stockholm, Sweden

4 Department of Chemistry, Faculty of Science, El-Menoufia University, Shebin El Kom, Egypt

5 Department of Chemistry, COMSATS Institute of Information Technology, Abbottabad 22060, Pakistan

6 Agricultural Research Centre, Cairo, Egypt

7 Department of Zoology, Faculty of Science, El-Menoufia University, Shebin El-Kom 32512, Egypt

8 Department of Molecular Biosciences, The Wenner-Gren Institute, Stockholm University, Stockholm 106 91, Sweden

9 Quaid-i-Azam University, Islamabad 45320, Pakistan

10 Pharmacognosy Department, College of Pharmacy, Cairo University, Kasr el Aini St., P.B. 11562, Cairo, Egypt

11 Department of Pharmacognosy, College of Pharmacy, King Saud University, P.O. Box 2457, Riyadh 11451, Saudi Arabia 
significant repellent activity against $I$. ricinus nymphs by $61.1 \%$. The most repellent plants $C$. dioscoridis, $C$. officinalis and A. herba-alba yielded essential oils by $0.17,0.11$ and $0.14 \%$, respectively. These oils were further investigated using gas chromatographymass spectrometry analysis. $\alpha$-Cadinol (10.7\%) and hexadecanoic acid $(10.5 \%)$ were the major components of $C$. dioscoridis whereas in $C$. officinalis, $\alpha$-cadinol (21.2\%) and carvone $(18.2 \%)$ were major components. Artemisia herba-alba contained piperitone $(26.5 \%)$, ethyl cinnamate $(9.5 \%)$, camphor $(7.7 \%)$ and hexadecanoic acid $(6.9 \%)$. Essential oils of these three plants have a potential to be used for personal protection against tick bites.

Keywords Ixodes ricinus - Essential oil · Chemical composition · Tick repellents $\cdot$ Gas chromatography-mass spectrometry $\cdot$ Egyptian flora

\section{Introduction}

Ticks belong to a group of exclusively blood-feeding ectoparasites (Elmhalli et al. 2009). From the medical point of view, ticks are the second most important group of disease vectors after mosquitoes. The pathogenic agents transmitted by ticks affect the public health and cause economic losses in livestock sector (Svehlova et al. 2014). The Mediterranean region offers suitable environment for a wide range of tick species (Maia et al. 2014). The geographical distribution of ticks has continued to increase over the past three decades (Tabanca et al. 2013; Svehlova et al. 2014). This distribution might be modified by future climate and environmental changes (Jore et al. 2014).

The common tick, Ixodes ricinus (L.) (Acari: Ixodidae), is a triphasic tick that parasitizes a large number of vertebrates including small, medium to large mammals; birds and lizards (Becker et al. 2009). The abundance of I. ricinus on different vegetation types in a wooded area of Southern Italy was determined by Dantas-Torres and Otranto (2013). They found that the abundance of I. ricinus larvae on the ground-level vegetation was generally higher than on the higher vegetation whereas both nymphs and adult stages were more abundant on higher vegetation. The questing behavior of I. ricinus consists of climbing the low vegetation to a point from where it can attach to the passing hosts. The host-seeking activity of the castor-bean tick indicated that this tick has a bimodal seasonal activity with a dominant peak during spring whereas a minor peak during autumn (Schulz et al. 2014). The immature stages (larvae and nymphs) feed on woodland birds and small to mediumsized mammals while the adult female feeds on large mammals. Each life stage (larva, nymph, adult) of this tick feeds once on different host for continuous period lasting several days (Heylen et al. 2013).

Ixodes ricinus is a potential vector of different pathogens. The cattle parasite, Babesia divergens (the causative agent of human's babesiosis) is transmitted to human by I. ricinus (Zintl et al. 2014). Spirochete, Borrelia burgdorferi sensu lato (the causative agent of Lyme disease) is considered diderm (double-membrane) bacteria with a worldwide distribution. Borrelia burgdorferi is mostly associated with I. ricinus complex in Northern Hemisphere. The density of questing I. ricinus in Northern Norway was determined for the first time by Hvidstena et al. (2015). They found that the overall prevalence of nymphs and 
adult ticks infected by $B$. burgdorferi s.l. was 21 and $46 \%$, respectively. The high incidence rate of reported Lyme borreliosis in Bonnoy region can be explained by the high Borreliainfection prevalence in ticks (Hvidstena et al. 2015). The encephalitis virus is transmitted to humans by $I$. ricinus nymphs and adults. The infection prevalence of tick-born-encephalitis virus (TBE) was significantly lower in I. ricinus nymphs $(0.51 \%)$ than adults (4.48\%) stage (Pettersson et al. 2014). Due to the role of I. ricinus tick in the transmitting of many serous pathogens, personal protection against bites of the infected stages of I. ricinus is essential.

Despite recent advances in tick control strategies, large-scale reduction of tick populations has not been achieved (Tabanca et al. 2013). The synthetic repellents are commonly accepted means of personal protection against tick bites (Iori et al. 2005). However, the use of such commercial synthetic acaricides leads to resistance, residual effects and potentially can harm the environment (Elmhalli et al. 2009). There is a direct need to establish alternative substances for tick control which are safer, available, cheaper and more effective (Frances and Wirtz 2005). Many essential oils (extracted from medicinal plants) considered as promising repellent agents against I. ricinus. The repellency of the oils appears to be largely associated with the presence of volatile terpenoid constituents.

As a part of our ongoing studies of bioactive constituents from plants commonly used in folk medicine (El-Seedi et al. 2012; Al-Henhen et al. 2014; Boldbaatar et al. 2014) with potential use in chemical ecology research, we here present results from 11 medicinal and culinary plants originating from Egypt. We isolated the essential oils and evaluated their bioactivity against the common tick I. ricinus and identified the main chemical constituents of these essential oils using gas chromatography-mass spectrometry (GC-MS).

\section{Materials and methods}

\section{Essential oils}

The air-dried ground parts of the plants (Table 1) were purchased from a commercial source in Cairo-Egypt. One hundred gram of each plant material was subjected to steam

Table 1 Essential oil yield of the 11 medicinal plants used in the current study

\begin{tabular}{|c|c|c|c|c|c|}
\hline No. & Latin name & Common Egyptian name & Family & Part used & $\%$ yield $(\mathrm{w} / \mathrm{w})$ \\
\hline 1 & Ammi majus L. & Khella barry & Apiaceae & Seeds & 0.09 \\
\hline 2 & Ammi visnaga $\mathrm{L}$. & Khella balady & Apiaceae & Seeds & 0.08 \\
\hline 3 & $\begin{array}{l}\text { Foeniculum vulgare } \\
\text { Mill. }\end{array}$ & Shammar & Apiaceae & Seeds & 1.1 \\
\hline 4 & Nerium oleander L. & Daflla & Apocynaceae & Leaf & 0.07 \\
\hline 5 & $\begin{array}{l}\text { Artemisia herba-alba } \\
\text { Asso }\end{array}$ & Sheih balady & Asteraceae & Leaf & 0.11 \\
\hline 6 & Calendula officinalis L. & Kanedula & Asteraceae & Flower & 0.14 \\
\hline 7 & Conyza dioscoridis $\mathrm{L}$. & Baranof & Asteraceae & Leaf & 0.17 \\
\hline 8 & Matricaria recutita L. & Sheih baboning & Asteraceae & Flower & 0.2 \\
\hline 9 & Ricinus communis $\mathrm{L}$. & Kharwae & Euphorbiaceae & Seeds & 0.01 \\
\hline 10 & Lawsonia inermis L. & Henna & Lythraceae & Leaf & 0.15 \\
\hline 11 & Lantana camara $\mathrm{L}$. & Lantana & Verbenaceae & Leaf & 0.18 \\
\hline
\end{tabular}


distillation for $4 \mathrm{~h}$. The distillate was collected and extracted three times with $100 \mathrm{ml}$ of HPLC grade n-hexane (VWR Int. Sweden), dehydrated using anhydrous magnesium sulfate (Alfa Aesar UK), filtered and solvent was evaporated using rotary evaporator at $20{ }^{\circ} \mathrm{C}$ under reduced pressure. The essential oils were weighed and reconstituted in hexane as $20 \mathrm{mg} / \mathrm{ml}$, stored in tightly closed glass vials in freezer at $-20{ }^{\circ} \mathrm{C}$ until further investigations.

\section{GC-MS analysis}

Separation and identification of volatiles from essential oils were carried out by GC-MS using a Varian 3400 GC connected to a Finnigan SSQ 7000 quadrupole mass spectrometer. $1 \mu \mathrm{l}$ aliquot containing $3 \mu \mathrm{g} / \mu \mathrm{l}$ of essential oil was injected to GC injector for analysis. The GC was equipped with a split/split less injector (split less mode, $30 \mathrm{~s}$; injector temperature, $230{ }^{\circ} \mathrm{C}$; carrier gas, Helium with a constant pressure of $10 \mathrm{psi}$ ). A DB-WAX capillary column ( $30 \mathrm{~m}, 0.25 \mathrm{~mm} \mathrm{ID,} \mathrm{and} 0.25 \mu \mathrm{m}$ film thickness, J \& W USA) was used. The temperature program was: $40{ }^{\circ} \mathrm{C}$ for $1 \mathrm{~min}$ then increased with a rate of $4{ }^{\circ} \mathrm{C} / \mathrm{min}$ up till $235^{\circ} \mathrm{C}$ and held at $235^{\circ} \mathrm{C}$ for $10 \mathrm{~min}$. Transfer line connecting GC to the MS was isothermally set to $240{ }^{\circ} \mathrm{C}$ throughout the analysis. The temperature of MS ion source was $150{ }^{\circ} \mathrm{C}$ and mass spectra were obtained at $70 \mathrm{eV}$ with a mass range of $30-400 \mathrm{~m} / \mathrm{z}$. Mass spectra of separated compounds were compared to the Finnigan NIST-2008 (National Institute of Standard and Technology) MS library and to available reference compounds (El-Seedi et al. 2008, 2010).

\section{Tick collection and maintenance}

Nymphs of I. ricinus were collected from the field during summer 2009 in Stockholm, Sweden using methods described by Garboui et al. (2007) and El-Seedi et al. (2012). Briefly, two wooden poles of $1 \mathrm{~m}$ length and $3 \mathrm{~cm}$ diameter were attached to two opposite sides of a white flannel cloth $(1 \times 1 \mathrm{~m})$ and a long string was tied on both ends of one wooden pool attached to the cloth. The cloth was dragged over the vegetation by holding string in hand whereas the two wooden poles made it possible to expand the cloth during dragging so that maximum cloth surface could be exposed and touch the vegetation. Nymphs attached to the cloth were removed with the help of soft forceps and put into tubes having wet filter paper. Nymphs were maintained in complete darkness at $4{ }^{\circ} \mathrm{C}$ and $80-95 \%$ relative humidity until they were used in laboratory bioassay. Before starting experiment the ticks were kept in room temperature for $24 \mathrm{~h}$.

\section{Laboratory bioassay}

To ascertain the repellent activity of the essential oils (EO) (at a concentration of $1 \mathrm{mg} / \mathrm{ml}$ ) extracted from plants (Table 2) against I. ricinus nymphs, the method described by Jaenson et al. (2003) and Garboui et al. (2007) was used. The walls of transparent-plastic Falcon tubes $(50 \mathrm{ml}$ centrifugal tube: $116 \times 29 \mathrm{~mm})$ were perforated, to prevent the internal air saturation with the observer odor, test or control substances. A $100 \mu 1$ of each EO solution $(1 \mathrm{mg} / \mathrm{ml})$ was applied evenly on a cotton cloth with a pipette to get a final concentration of $15 \mu \mathrm{g} / \mathrm{cm}^{2}$. Control cotton cloths were treated with $100 \mu \mathrm{l}$ hexane. The treated and control cloths were air dried for 2 min for solvent evaporation. Freshly collected unfed I. ricinus nymph was introduced into Falcon tube and firstly tested with hexane treated cloth (that 
Table 2 Percentage of repellency of essential oils of different plants based on percentages of Ixodes ricinus nymphs attracted to test and control (hexane) in lab bioassay

\begin{tabular}{|c|c|c|c|c|c|}
\hline \multirow[t]{2}{*}{ Tested essential oil } & \multirow[t]{2}{*}{$\mathrm{N}$} & \multicolumn{2}{|c|}{$\%$ attracted ticks } & \multirow[t]{2}{*}{$P$} & \multirow[t]{2}{*}{$\%$ repellency } \\
\hline & & Control & Test & & \\
\hline Ammi majus & 6 & 95 & 30 & 0.024 & 68.3 \\
\hline Ammi visnaga & 6 & 80 & 30 & 0.026 & 62.4 \\
\hline Foeniculum vulgare & 6 & 85 & 25 & 0.024 & 70.6 \\
\hline Nerium oleander & 6 & 95 & 37 & 0.026 & 60.0 \\
\hline Artemisia herba-alba & 6 & 95 & 15 & 0.024 & 84.2 \\
\hline Calendula officinalis & 6 & 85 & 15 & 0.024 & 82.0 \\
\hline Conyza dioscoridis & 6 & 83 & 5 & 0.02 & 94.0 \\
\hline Matricaria recutita & 6 & 95 & 57 & 0.02 & 40.0 \\
\hline Ricinus communis & 6 & 93 & 35 & 0.027 & 61.2 \\
\hline Lawsonia inermis & 6 & 85 & 35 & 0.024 & 58.3 \\
\hline Lantana camara & 6 & 95 & 35 & 0.014 & 63.3 \\
\hline $98 \%$ DEET $^{\mathrm{a}}$ & 10 & 70 & 0 & $<0.001$ & 100.0 \\
\hline $19 \%$ DEET & 10 & 84 & 4 & $<0.001$ & 95.2 \\
\hline $10 \%$ DEET & 10 & 92 & 14 & $<0.001$ & 84.8 \\
\hline
\end{tabular}

${ }^{a} N, N$-diethyl- $m$-toluamide (DEET) data was extracted from Jaenson et al. (2003)

fixed to the Falcon upper end with the help of rubber band) for 5 min and immediately after the same nymph was tested against the EO treated cloth for another $5 \mathrm{~min}$ (one cloth used for each nymph). In order to simulate the nymph, the observer held his hand palm on the outer surface of the cloth during the observation period $(5 \mathrm{~min}$ ). The same observer conducted the entire bioassay who was attractive to ticks. A tick nymph was considered "attracted" to the cloth if it detached all its legs from the wall of the Falcon tube and clung towards the treated cloth within $5 \mathrm{~min}$, whereas the nymph which failed to reach the cloth in this time or/and turned around the Falcon tube wall was regarded as "repelled" (ElSeedi et al. 2012). Ten nymphs were used/each oil/each replicate. Five replicates were used, thus the overall tick number was 50 nymphs for each EO and control group. The percentage of repellency was calculated using the formula of Jaenson et al. (2005) as follows:

$\%$ repellency $=[$ (number of nymphs recorded as "attracted" in the control vial - number of nymphs recorded as "attracted in the test vial)/number of nymphs recorded as "attracted" in the control vial] $\times 100$.

\section{Field experiment}

In order to test the tick repelling activity under natural conditions, a field trial was conducted using the similar white flannel cloths that used for tick collection mentioned above. The field trail was employed using method described by Garboui et al. (2007). Briefly, two persons dragged two white flannel clothes $(1 \times 1 \mathrm{~m})$ on vegetation in parallel manner. One cloth was sprayed with $65 \mathrm{mg}$ of the test substance dissolved in $100 \mathrm{ml}$ hexane to cover the whole surface of the cloth whereas the other cloth was sprayed with $100 \mathrm{ml}$ hexane control. 
The final concentration of essential oil was $6.5 \mu \mathrm{g} / \mathrm{cm}^{2}$ of the cloth. During the trial the clothes were dragged against the vegetation in such a way that the treated side was towards the ground vegetation to maximize the effect of the treatment. The cloths were slowly dragged over an area of $10 \mathrm{~m}^{2}$ before they were inspected and attached ticks were counted, removed and put into separate labeled vials. This procedure was repeated 20 times per day for the test substance and the control thus overall a tested cloth was dragged over a vegetation of $200 \mathrm{~m}^{2}$. The treated clothes were tested for two consecutive days and were stored separately in airtight plastic bags until the next day of testing. Temperature and humidity were recorded the day before, during testing days and one day after the test. The repellency of essential oil was calculated (Jaenson et al. 2005) using the following formula:

$\%$ repellency $=[($ no. of nymphs on control cloth - no. of nymphs on test cloth $) /$ no. of nymphs on control cloth] $\times 100$.

\section{Statistical analysis}

Wilcoxon match pair test was employed on lab bioassay data whereas Mann-Whitney $U$ test was used to find the difference $(\alpha=0.05)$ between control and essential oil treated clothes. The tests were performed in SPSS 20.0 (IBM USA).

\section{Results}

\section{Isolation of essential oils}

Eleven plants originating from Egypt were investigated as potentially active against blood sucking ticks. The Egyptian plants used in the present study (Table 1) were found to be rich in essential oils, which were obtained by steam distillation. The largest yield of essential oil was obtained from the seeds of Foeniculum vulgare Mill. (1.1\%) followed by Matricaria recutita L. (0.2\%), whereas Ricinus communis L. exhibited the lowest yield $(0.01 \%)$. Furthermore, the oils obtained from Conyza dioscoridis L., Calendula officinalis L. and Artemisia herba-alba Asso were 0.17, 0.14 and $0.11 \%$ yield, respectively (Table 1).

\section{Chemical analysis}

The constituents of each plant essential oil and their relative percentage based on the total ion current chromatogram are summarized in Table 3. Most of the compounds were oxygented mono- and sesquiterpenoids and a few aromatic monoterpenes. In the essential oils the number of compounds, representing percentage of oil, were identified as follows; Ammi majus 20 (87.7\%), A. visnaga 13 (95.3\%), F. vulgare 6 (98.1\%), Nerium oleander 33 (93.5\%), A. herba alba 21 (91.3\%), C. officinalis 24 (85.4\%), C. dioscoridis 33 (84.1\%), M. recutita 12 (94.1\%), R. communis 26 (86.4\%), Lawsonia inermis 27 (67.2\%), Lantana camara 15 (80.9\%), are presented in Table 3.

Major components of $A$. majus essential oil were hexadecanoic acid (38\%), dihydrocarvone (7\%), 6-octadecenoic acid (6.4\%) and tetradecanoic acid (4.9\%) representing $56.3 \%$ of oil. The main compounds of $A$. visnaga essential oil were carvone (57\%) and apiol $(18.1 \%)$ constituting $75.1 \%$ of oil (Table 3 ).

The A. herba alba essential oil contained piperitone (26.5\%), ethyl cinnamate $(9.5 \%)$, camphor $(7.7 \%)$ and hexadecanoic acid $(6.9 \%)$ as major compounds representing $50.6 \%$ of 


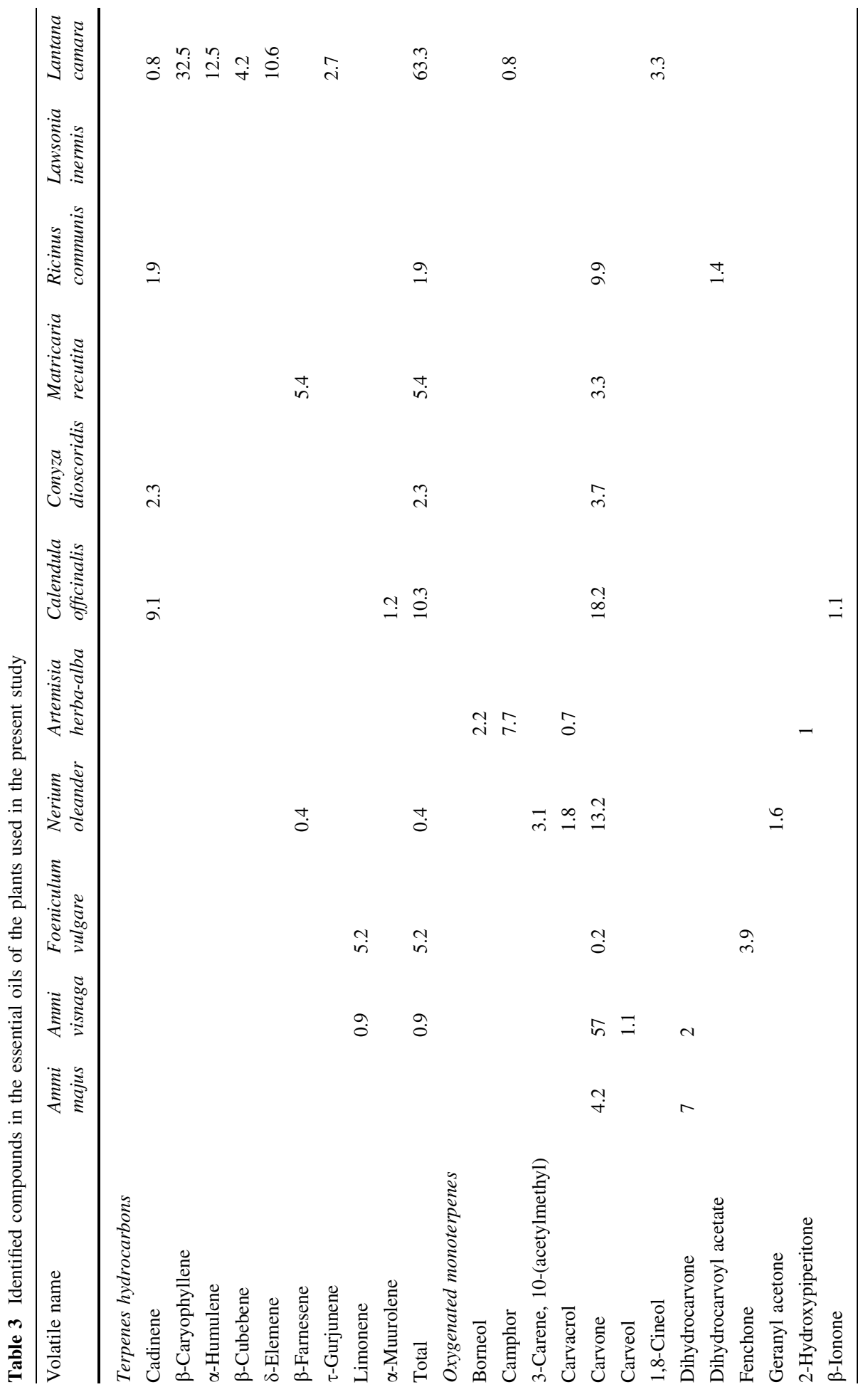




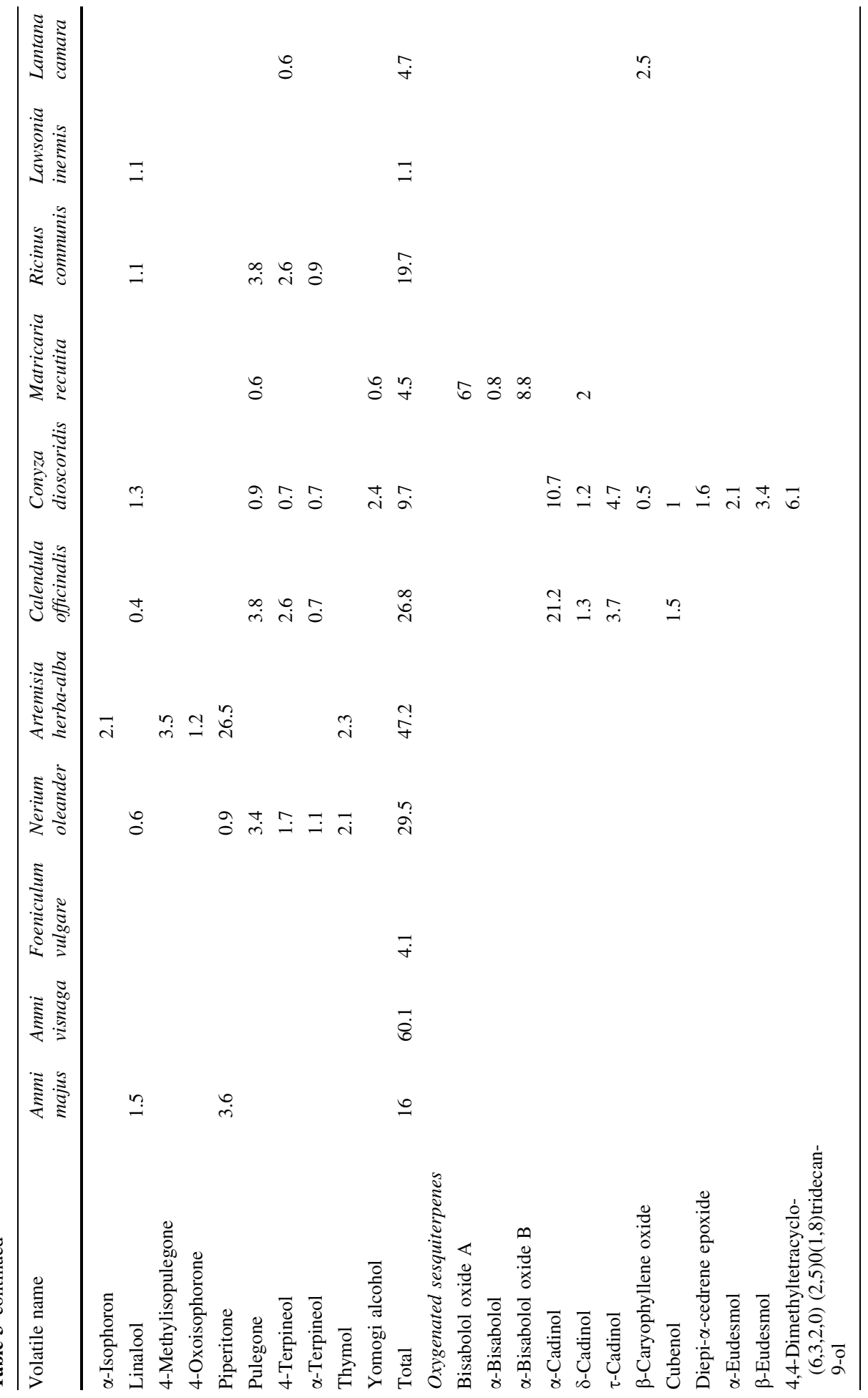




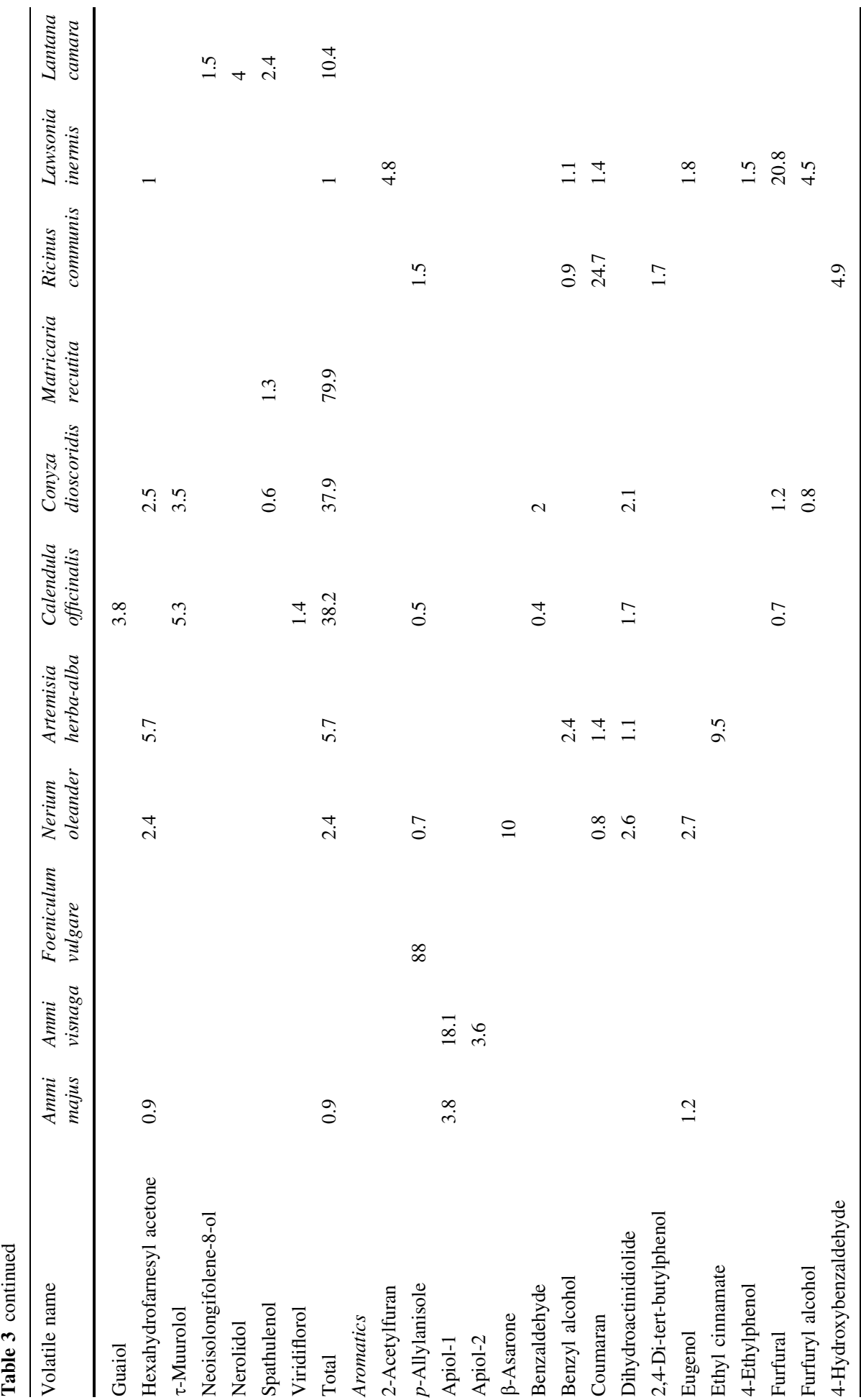




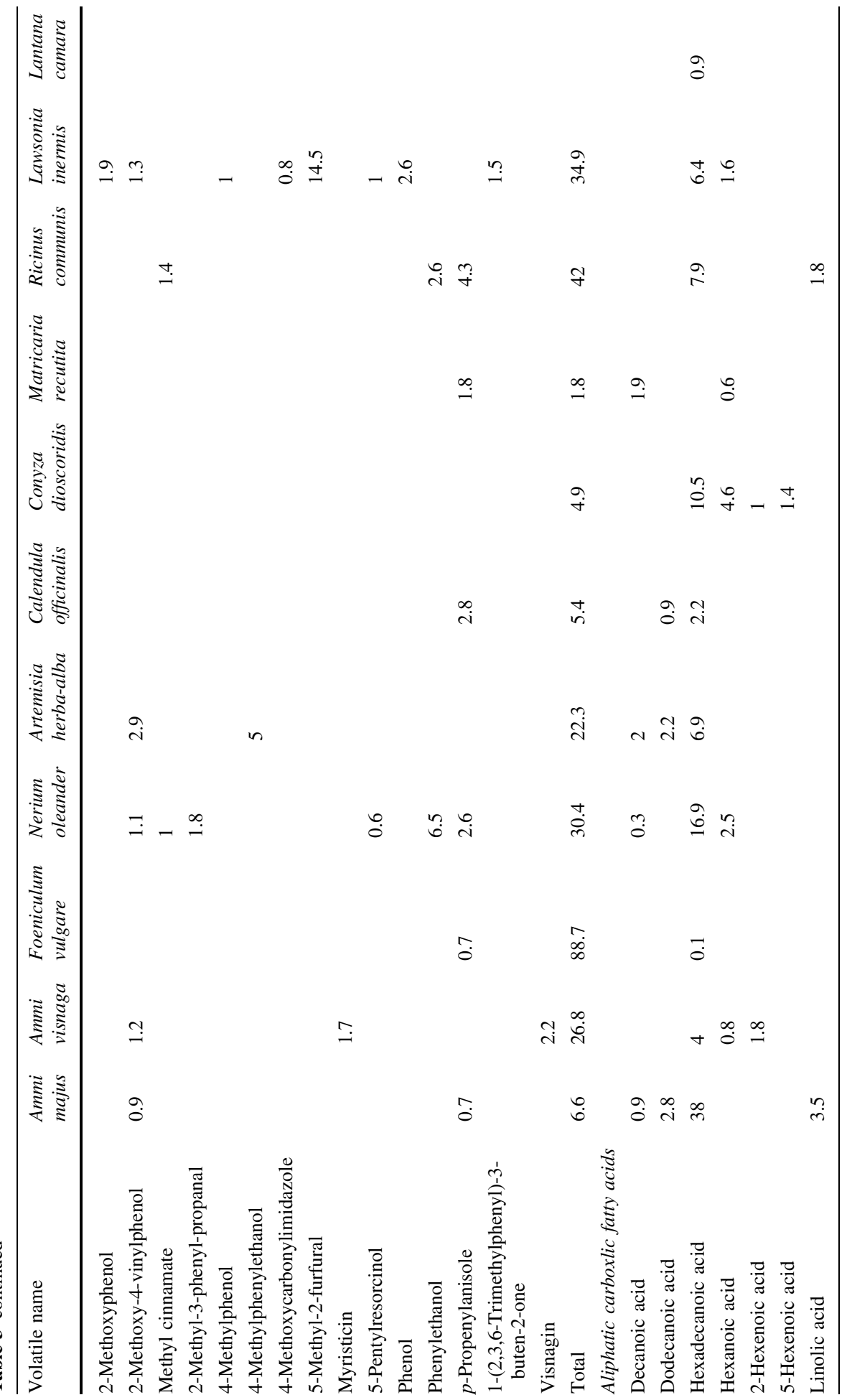




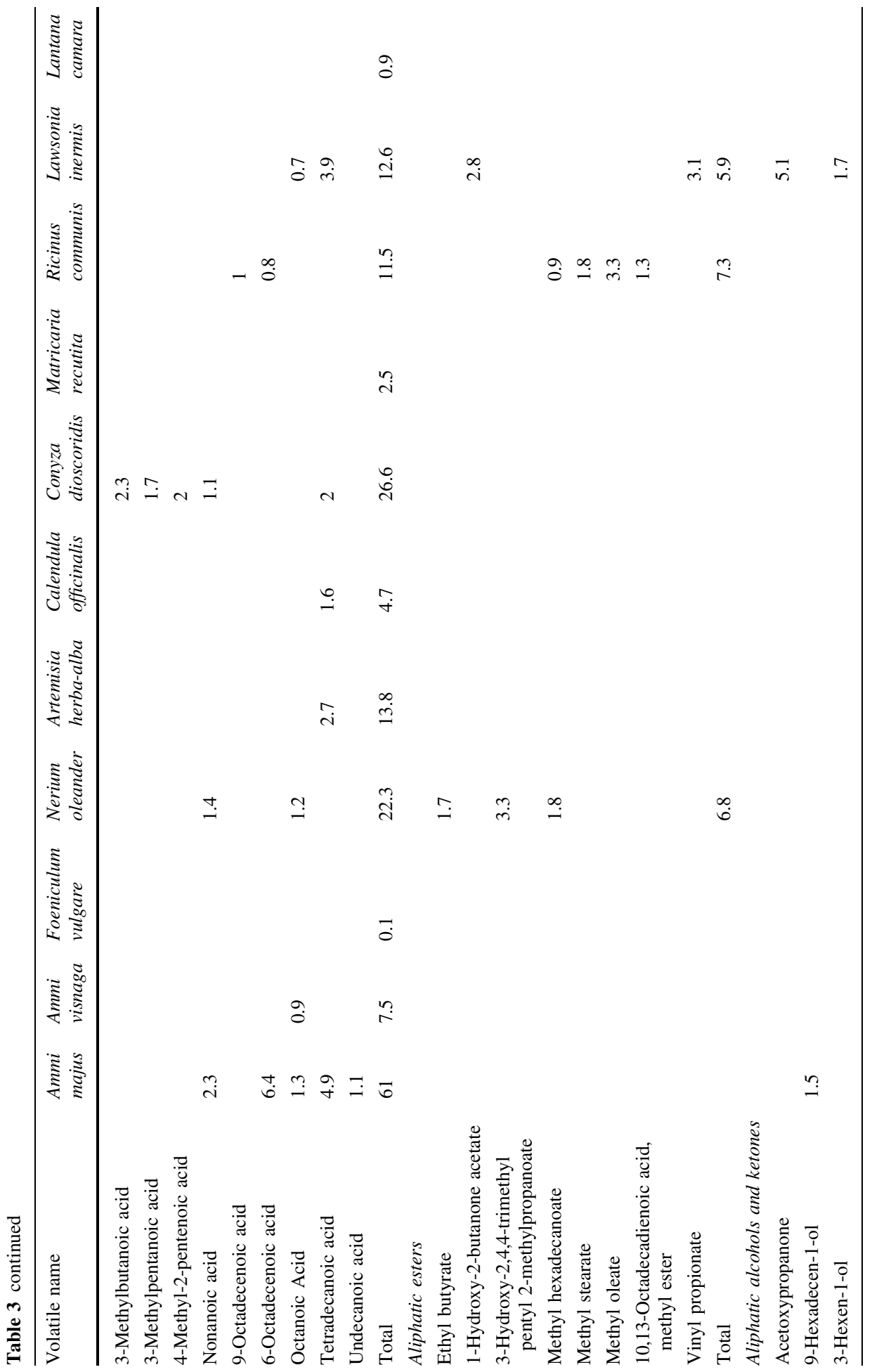




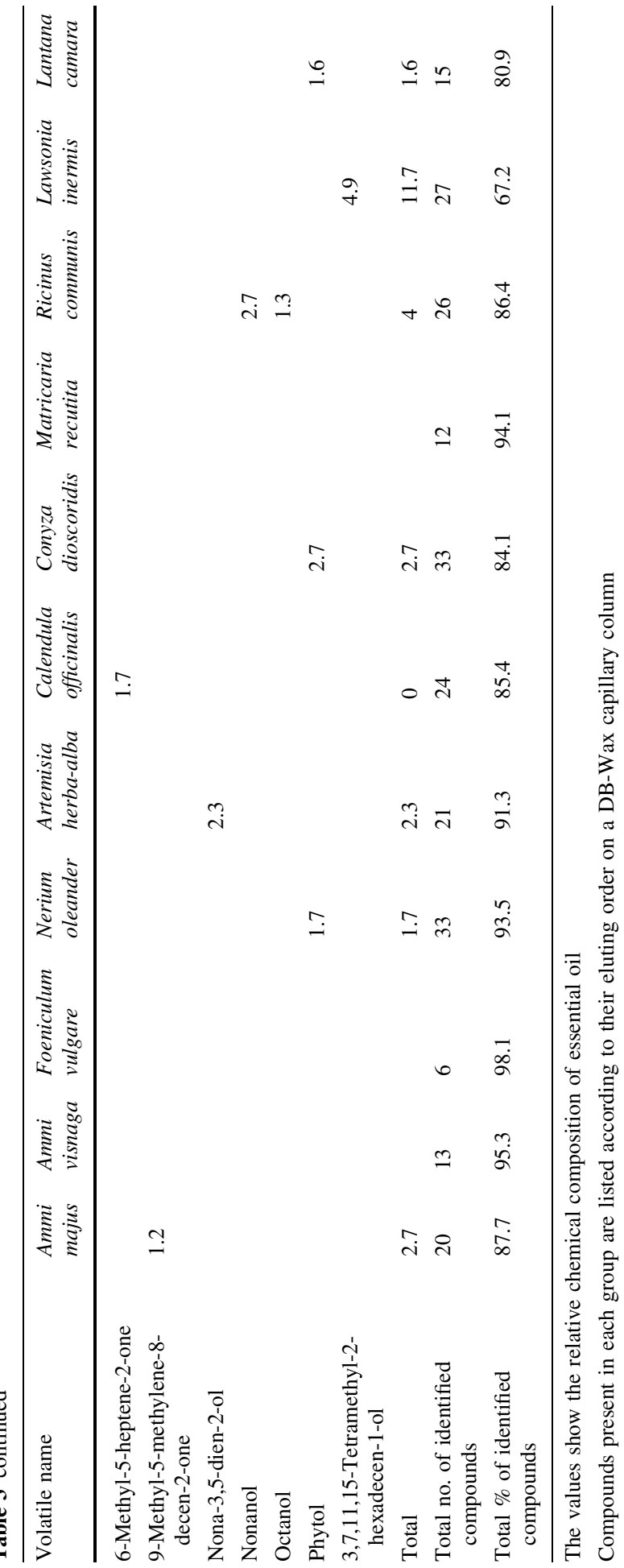


the oil. The major constituents of $C$. officinalis oil were $\alpha$-cadinol (21.2\%), carvone (18.2\%) and cadinene (9.1\%) those representing $48.5 \%$ of the oil (Table 3).

The main compounds of $C$. dioscoridis oil were $\alpha$-cadinol $(10.7 \%)$, hexadecanoic acid (10.5\%), 4,4-dimethyltetracyclo-(6,3,2,0)(2,5)0(1,8)tridecan-9-ol $\quad(6.1 \%), \quad \tau$-cadinol (4.7\%), hexanoic acid (4.6\%), carvone $(3.7 \%)$ and $\tau$-muurolol $(3.5 \%)$ and representing $43.8 \%$ of the oil (Table 3). p-Allylanisole (88\%) and limonene (5.2\%) constituted the major part of $F$. vulgare essential oil.

$\beta$-Caryophyllene $(32.5 \%)$, furfural $(20.8 \%)$, bisabolol oxide A $(67 \%)$, hexadecanoic acid $(16.9 \%)$ and coumaran $(24.7 \%)$ were the major compounds of L. camara, L. inermis, $M$. recutita, $N$. oleander and $R$. communis essential oils, respectively (Table 3 ).

\section{Laboratory bioassay}

Experimental results revealed that all essential oils from eleven Egyptian plants were to various degree repellent to I. ricinus nymphs. The most active essential oils were C. dioscoridis, A. herba alba and $C$. officinalis that elicited strong repellent activity against tick nymphs by $94,84.2$ and $82.0 \%$, respectively (Table 2 ). The F. vulgare and A. majus oils revealed moderate repellent activity by 70.6 and $68.3 \%$, respectively. The oils from L. camara, A. visnaga, $R$. communis, and $N$. oleander elicited repellency by $63.3,62.4$, 61.2 , and $60 \%$, respectively. A minimum repellent activity was observed by the oils of $L$. inermis and $M$. recutita (Table 2).

\section{Field study}

Laboratory bioassay data revealed that the essential oil of $C$. dioscoridis exhibited strongest repellency toward ticks compared to all other essential oils. Therefore, the essential oil of $C$. dioscoridis was applied in the field trail at a concentration of $6.5 \mu \mathrm{g} / \mathrm{cm}^{2}$. This oil elicited a significant repellent activity against $I$. ricinus nymphs on two consecutive days $(P<0.05$, Fig. 1).

\section{Discussion}

There is a great potential for the use of plants from Africa, Asia and South America tropical and subtropical regions for finding new bioactive molecules and for our purposes new compounds for tick control (Habeeb 2010). In Table 4 numerous candidates with putative repellency activity are listed and oxygenated monoterpenes and sesquiterpenes are

Fig. 1 Mean number of ticks attracted toward control and Conyza dioscoridis essential oil treated clothes in the field trial. Columns with different letters are significantly different from each other $(P<0.05)$

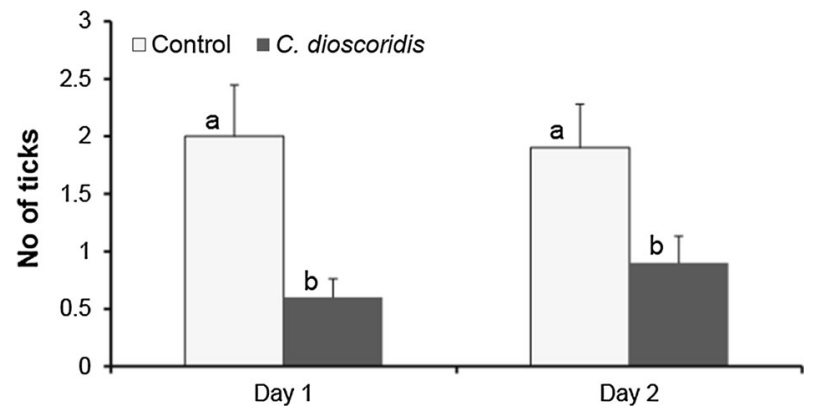


Table 4 Plants with repellent activity against Ixodes ricinus and some of their major chemical constituents which might contribute to their activity

\begin{tabular}{|c|c|c|c|c|c|}
\hline Plant essential oil & Family & Plant part & Chemical ingredients & $\%$ repellency & References \\
\hline $\begin{array}{l}\text { Cymbopogon spp. } \\
(10 \%(\mathrm{w} / \mathrm{w}) \mathrm{in} \\
\text { ethanol) }\end{array}$ & Poaceae & $\begin{array}{l}\text { Commercial } \\
\text { oil } \\
\text { (Stockholms } \\
\text { Aether \& } \\
\text { Essence } \\
\text { fabrik) }\end{array}$ & Citronellol, Geraniol & 90 after $6 \mathrm{~h}$ & $\begin{array}{l}\text { Thorsell } \\
\text { et al. } \\
(2006)\end{array}$ \\
\hline $\begin{array}{l}\text { Syzygium } \\
\text { aromaticum } \\
(10 \%(\mathrm{w} / \mathrm{w}) \text { in } \\
\text { ethanol) }\end{array}$ & Myrtaceae & $\begin{array}{l}\text { Commercial } \\
\text { oil } \\
\text { (Stockholms } \\
\text { Aether \& } \\
\text { Essence } \\
\text { fabrik }\end{array}$ & Eugenol & 82 after $6 \mathrm{~h}$ & $\begin{array}{l}\text { Thorsell } \\
\text { et al. } \\
(2006)\end{array}$ \\
\hline $\begin{array}{l}\text { Rhododendron } \\
\text { tomentosum } \\
\text { (10\% in } \\
\text { acetone) }\end{array}$ & Ericaceae & Leaves & $\begin{array}{l}\text { Palustrol }(22.8 \%), \\
\text { Myrcene }(21.3 \%), \\
\text { Ledol }(6.1 \%), 2,6- \\
\text { Dimethyl-1,5,7- } \\
\text { octatriene-3-ol } \\
(4.1 \%), \\
\text { Alloaromadendrene } \\
(2.8 \%)\end{array}$ & $\begin{array}{l}95.1 \\
\quad \text { (laboratory } \\
\text { experiment) }\end{array}$ & $\begin{array}{l}\text { Jaenson } \\
\text { et al. } \\
(2005)\end{array}$ \\
\hline $\begin{array}{l}\text { Myrica gale }(10 \% \\
\text { in acetone) }\end{array}$ & Myricaceae & Leaves & $\begin{array}{l}\text { (3Z)-Hexenol } \\
(18.3 \%), \\
\text { 4-Hydroxy-4- } \\
\text { methylpentane-2- } \\
\text { one }(10.2 \%), \\
\text { Cadinadiene }(8.4 \%), \\
\alpha \text {-Trpineol }(6.2 \%), \\
\text { 4-Terpineol }(5.8 \%)\end{array}$ & $\begin{array}{l}48.5 \\
\quad \text { (laboratory } \\
\text { experiment) }\end{array}$ & $\begin{array}{l}\text { Jaenson } \\
\text { et al. } \\
(2005)\end{array}$ \\
\hline $\begin{array}{l}\text { Corymbia } \\
\text { citriodora ( } 30 \% \\
\text { in acetone for } \\
\text { field } \\
\text { experiment) }\end{array}$ & Myrtaceae & & $\begin{array}{l}\text { cis- and trans- } \\
\text { p-Menthane-3,8- } \\
\text { diol (PMD) }\end{array}$ & $\begin{array}{l}100 \\
\text { (laboratory } \\
\text { experiment), } \\
85 \text { (field } \\
\text { experiment) }\end{array}$ & $\begin{array}{l}\text { Jaenson } \\
\text { et al. } \\
\text { (2006) }\end{array}$ \\
\hline $\begin{array}{l}\text { Pelargonium } \\
\text { graveolens } \\
\text { (30\% in 1,2- } \\
\text { propanediol) }\end{array}$ & Geraniaceae & & $\begin{array}{l}\text { No chemical } \\
\text { composition } \\
\text { reported }\end{array}$ & $\begin{array}{l}100 \\
\text { (laboratory } \\
\text { experiment) }\end{array}$ & $\begin{array}{l}\text { Jaenson } \\
\text { et al. } \\
\text { (2006) }\end{array}$ \\
\hline $\begin{array}{l}\text { Lavandula } \\
\text { angustifolia } \\
\text { (30\% in 1,2- } \\
\text { propanediol) }\end{array}$ & Lamiaceae & & $\begin{array}{l}\text { No chemical } \\
\text { composition } \\
\text { reported }\end{array}$ & $\begin{array}{l}100 \\
\text { (laboratory } \\
\text { experiment) }\end{array}$ & $\begin{array}{l}\text { Jaenson } \\
\text { et al. } \\
\text { (2006) }\end{array}$ \\
\hline $\begin{array}{l}\text { Mentha spicata } \\
(0.1 \% \mathrm{w} / \mathrm{v} \text { in } \\
\text { hexane) }(15 \% \\
\mu \mathrm{g} / \mathrm{cm}^{2} \text { for lab } \\
\text { experiment, } \\
6.5 \mu \mathrm{g} / \mathrm{cm}^{2} \text { for } \\
\text { field } \\
\text { experiment })\end{array}$ & Lamiaceae & Leaves & $\begin{array}{l}\text { Carvone }(54.7 \%), \\
\text { Pulegone }(14.2 \%), \\
\text { 1,8-Cineole }(4.7 \%)\end{array}$ & $\begin{array}{l}93.2 \\
\quad \text { (laboratory } \\
\text { experiment), } \\
59.4 \text { (field } \\
\text { experiment) }\end{array}$ & $\begin{array}{l}\text { El-Seedi } \\
\text { et al. } \\
(2012)\end{array}$ \\
\hline
\end{tabular}


Table 4 continued

\begin{tabular}{|c|c|c|c|c|c|}
\hline Plant essential oil & Family & Plant part & Chemical ingredients & $\%$ repellency & References \\
\hline $\begin{array}{l}\text { Ocimum } \\
\text { basilicum }(0.1 \% \\
\text { w/v in hexane }) \\
\left(15 \% \mu \mathrm{g} / \mathrm{cm}^{2}\right)\end{array}$ & Lamiaceae & Leaves & $\begin{array}{l}\text { Linalool }(27.8 \%), \\
\text { Estragole }(12.3 \%), \\
\text { Methyl trans } \\
\text { cinnamate }(11.8 \%), \\
\text { Eugenol }(9 \%), 1,8- \\
\text { Cineole }(6.6 \%)\end{array}$ & $\begin{array}{l}64.5 \\
\text { (laboratory } \\
\text { experiment) }\end{array}$ & $\begin{array}{l}\text { El-Seedi } \\
\text { et al. } \\
\text { (2012) }\end{array}$ \\
\hline $\begin{array}{l}\text { Rosmarinus } \\
\text { officinalis } \\
(0.1 \% \mathrm{w} / \mathrm{v} \text { in } \\
\text { hexane) }(15 \% \\
\mu \mathrm{g} / \mathrm{cm}^{2} \text { for lab } \\
\text { experiment, } \\
6.5 \mu \mathrm{g} / \mathrm{cm}^{2} \text { for } \\
\text { field } \\
\text { experiment })\end{array}$ & Lamiaceae & Leaves & $\begin{array}{c}\text { 1,8-Cineole }(51.8 \%), \\
\text { Borneol (17.5\%), } \\
\text { Camphor }(12.8 \%)\end{array}$ & $\begin{array}{l}100 \\
\text { (laboratory } \\
\text { experiment), } \\
68.3 \text { (field } \\
\text { experiment) }\end{array}$ & $\begin{array}{l}\text { El-Seedi } \\
\text { et al. } \\
\text { (2012) }\end{array}$ \\
\hline $\begin{array}{l}\text { Origanum } \\
\text { majorana }(0.1 \% \\
\text { W/V in hexane }) \\
\left(15 \% \mu \mathrm{g} / \mathrm{cm}^{2}\right)\end{array}$ & Lamiaceae & Leaves & $\begin{array}{l}\text { 4-Terpineol }(55.6 \%) \\
\alpha \text {-Terpineol }(9.5 \%) \\
\text { Linalool }(3.7 \%)\end{array}$ & $\begin{array}{l}84.3 \\
\quad \text { (laboratory } \\
\text { experiment) }\end{array}$ & $\begin{array}{l}\text { El-Seedi } \\
\text { et al. } \\
\text { (2012) }\end{array}$ \\
\hline
\end{tabular}

among the most frequently identified compounds. A number of plants have earlier shown repellent activity against $I$. ricinus nymph and the majority of the compounds are oxygenated monoterpenes (Table 4). The present study exhibited repellent activity of essential oils extracted from eleven Egyptian medicinal plants against $I$. ricinus nymphs. Among the studied essential oils $C$. dioscoridis, A. herba alba and $C$. officinalis exhibited a strong repellency for ticks in laboratory bioassays. These three plants are belonged to Asteraceae family and showed the presence of a number of major compounds that might be responsible for their bioactivity.

Usually the biological activity of a plant extract is due the presence of one or more major compounds (El-Seedi et al. 2012) but in the case of $C$. dioscoridis essential oil, it seems the greater activity is due to presence of blend of diverse type of compounds which might have additional or synergistic effects. However, in case of $C$. officinalis there was a number of major compounds which could be responsible for its higher activity. $C$. dioscoridis and $C$. officinalis produced the same oxygenated sesquiterpene as major compounds but the amount and bioactivity was slightly different between species. The most abundant compound of these plant oils was $\alpha$-cadinol that was detected only in the essential oils of these two plants. $\alpha$-Cadinol was found to be highly effective for controlling two house mite species Dermatophagoides pteronyssinus and D. farinae (Chang et al. 2001).

The chemical composition of $C$. dioscoridis in the present study is partly in accordance with Grace (2002), where he presented the essential oil of Pluchea (=Conyza) dioscoridis which consisted of both sesquiterpene hydrocarbons and oxygenated sesquiterpenes in large proportions with $\alpha$-cadinol as the major constituent. However, our results are different from other previous studies (Nassar et al. 2014; Elshamy et al. 2015). Both studies showed that the major constituents of $C$. dioscoridis essential oil were mainly sesquiterpene hydrocarbons comprising more than $40 \%$ of the oil whereas there are more of oxygenated sesquiterpenes in the present essential oil. This difference in chemical composition 
might partly be explained by harvesting time, soil fertility, cultivation and drying methods of the plant materials have a significant impact on the chemical composition of essential oils (Okoh et al. 2007, 2008; Hussain et al. 2008; Omer et al. 2008; Antal et al. 2011). The effect of soil type and the seasonal variations on the quality and quantity of essential oil constituents was investigated by Omer et al. (2008) and Hussain et al. (2008). There is also a correlation between the age of plants and their essential oil yield and composition (Okoh et al. 2007) as well as harvesting season of three rose-scented geranium (Pelargonium grayeolens L'Her ex Ait; Geraniaceae) cultivars (Verma et al. 2013).

The Egyptian $C$. officinalis studied here with $\alpha$-cadinol as major component of the essential oil and is in accordance with previous studies conducted in South Africa (Okoh et al. 2007) and Brazil (Gazim et al. 2008). The effect of plant age on the yield and constituents of the oil extracted from the $C$. officinalis grown in South Africa was determined by Okoh et al. (2007) and found that the most interesting stage is the post-flowering period, the oil of which rich in $\alpha$-cadinene, $\alpha$-cadinol, $\tau$-muurolol, limonene and 1,8cineole. Gazim et al. (2008) stated the presence of $\alpha$-cadinol in Brazilian $C$. officinalis essential oil. The species has a long history in traditional medicine as Ibn El Bitar reported the use of this species in the treatment of epilepsy and as remedy for cold, colic and rheumatic pains (Boulos and El-Hadidi 1984).

Furthermore, different chemotypes of A. herba alba have been previously described originating from different localities. Identification of Sinai chemotype was achieved by GC-MS and two main oils were discerned, the cineole-bornane type and pinene type. The oils were rich in monoterpenes but did not contain any sesquiterpene components (Feuerstein et al. 1986). This is not consistent with our findings where we found piperitone as main compound. Essential oil of A. herba alba from Israel revealed the presence of sesquiterpene lactone and oxygenated monoterpenes (Segal et al. 1985). The population in Israel consist of a larger number of chemotypes of $A$. herba alba than was previously believed (Fleisher et al. 2002). An additional A. herba alba chemotype was described in Spain (Salido et al. 2004). Some Tunisian A. herba alba chemotypes showed the presence of similar compounds as in our essential oil however, the composition of the constituents was different (Mohsen and Ali 2009). Another study from A. herba alba essential oil from Tunisia described the presence of a number of potential tick repellent compounds; $\alpha$ thujone (24.9\%), germacrene D (14.5\%), camphor (10.8\%), 1,8-cineole (8.9\%), $\beta$-thujone (8.3\%), chrysanthenone (4.7\%) and borneol (3.1\%) in Kadri et al. (2011).

The repellency of A. majus (68.3\%) essential oil towards tick I. ricinus in the present study could be explained by the presence of carvone, dihydrocarvone and piperitone. These three in combination are possible candidates for the repellent activity. The essential oil of $F$. vulgare consisted of only six compounds contributing more than $98 \%$ of the oil. Limonene, $p$-allylanisole, and fenchone were the most abundant compounds in this essential oil that could be responsible for its biological activity. Limonene is used as an insecticide to control ectoparasites and has activity against many plant-feeding insects as the pine weevil (Nordlander 1990), mites and microorganisms (Ibrahim et al. 2001). Fenchone is reported to show mosquito repellent activity (Kim et al. 2002).

Ricinus communis, A. visnaga and $N$. oleander showed a moderate activity which might partly be due to the presence of carvone. Previously, carvone has shown antifeedants properties for the pine weevil Hylobius abietis (Schlyter et al. 2004) and repellent activity against flour beetle Tribolium castaneum (Caballero-Gallardo et al. 2011). The Environmental Protection Agency (EPA, USA, 2009) was reviewing a request to register it as a pesticide. $S$-(+)-Carvone is also used to prevent premature sprouting of potatoes during 
storage, being marketed in the Netherlands for this purpose under the name Talent (de Carvalho and da Fonseca 2006).

All the analyzed plants, exhibited repellent behavior against I. ricinus and all the oils contained oxygenated terpenes. However, the most active essential oils did not have similar volatile profiles. The current result strongly indicate that the oils contain a number of compounds having repellent properties and that many of them belong to the oxygenated group of monoterpenes and sesquiterpenes. The recent analyses did not include separation of the enantiomers of the chiral constituents. This lacking information might explain why essential oils with similar constituents have different repellent activity. However, it seems unlikely to find a specific compound in common that can explain the whole repellent activity, and most probably there is a combined effect of several constituents (Jaenson et al. 2005). The essential oils containing many tick repellent compounds might then be more useful and sustainable in tick control strategies.

Our study evaluated the potential of 11 plant essential oils and the oil of $C$. dioscoridis was found to be the most effective in the laboratory bioassay, moreover, it also proved to be a good repellent in the field trial. Therefore, $C$. dioscoridis oil might be useful sources of chemicals for controlling arthropods of medical, veterinary, or agricultural importance.

Acknowledgements We are grateful to Sida SRL, who supported the chemical analyses and travel to Egypt for both H.R. El-Seedi and A.-K. Borg-Karlson; to HEC Pakistan for financial support to M. Azeem, to EU Mobilitas MTT2 "Chemical ecology" for support to A-.K. Borg-Karlson, to UM, Malaysia for support to H.R. El-Seedi and the Alexander von Humboldt foundation, Germany to M. A. Farag for support his laboratory. M. F. AlAjmi is very grateful to the generous support provided by deanship of research, King Saud University under research group number RGP-150.

Open Access This article is distributed under the terms of the Creative Commons Attribution 4.0 International License (http://creativecommons.org/licenses/by/4.0/), which permits unrestricted use, distribution, and reproduction in any medium, provided you give appropriate credit to the original author(s) and the source, provide a link to the Creative Commons license, and indicate if changes were made.

\section{References}

Al-Henhen N, Yuen Ying RP, Ismail S, Najm W, Khalifa SAM, El-Seedi HR, Abdulla MA (2014) Chemopreventive efficacy of Andrographis paniculata on azoxymethane-induced aberrant colon crypt foci in vitro. PLoS ONE 9:e111118. doi:10.1371/journal.pone.0111118

Antal T, Figiel A, Kerekes B, Sikolya L (2011) Effect of drying methods on the quality of the essential oil of spearmint leaves (Mentha spicata L.). Dry Technol 29:1836-1844

Becker CAM, Bouju-Albert A, Jouglin M, Chauvin A, Malandrin L (2009) Natural transmission of zoonotic Babesia spp. by Ixodes ricinus ticks. Emerg Infect Dis 15:320-322

Boldbaatar D, El-Seedi HR, Findakly M, Jabri S, Javzan B, Choidash B, Göransson U, Hellman B (2014) Antigenotoxic and antioxidant effects of the Mongolian medicinal plant Leptopyrum fumarioides (L): an in vitro study. J Ethnopharmacol 155:599-606

Boulos L, El-Hadidi MN (1984) The weed flora of Egypt. American University in Cairo Press, Cairo

Caballero-Gallardo K, Olivero-Verbel J, Stashenko EE (2011) Repellent activity of essential oils and some of their individual constituents against Tribolium castaneum Herbst. J Agric Food Chem 59:1690-1696

Chang ST, Chen PF, Wang SY, Wu HH (2001) Antimite activity of essential oils and their constituents from Taiwania cryptomerioides. J Med Entomol 38:455-457

Dantas-Torres F, Otranto D (2013) Seasonal dynamics of Ixodes ricinus on ground level and higher vegetation in a preserved wooded area in southern Europe. Vet Parasitol 192:253-258

de Carvalho CCCR, da Fonseca MMR (2006) Carvone: why and how should one bother to produce this terpene. Food Chem 95:413-422 
Elmhalli FH, Pålsson K, Orberg J, Jaenson TGT (2009) Acaricidal effects of Corymbia citriodora oil containing para-menthane-3,8-diol against nymphs of Ixodes ricinus (Acari: Ixodidae). Exp Appl Acarol 48:251-262

El-Seedi HR, Khattab A, Gaara AHM, Mohamed TK, Hassan NA, El-Kattan AE (2008) Essential oil analysis of Micromeria nubigena HBK and its antimicrobial activity. J Essent Oil Res 20:452-456

El-Seedi HR, Zayed M, Roshdy S, Salem M, Hawata M, El-Essawy F, El-Barbary M, El-Kousy S (2010) Analysis of the essential oil from the aerial parts of Psoralea pubescence (Miq.) Standl and its antibacterial activity. Med Chem Res 19:1036-1042

El-Seedi HR, Khalil NS, Azeem M, Taher E, Göransson U, Pålsson K, Borg-Karlson A-K (2012) Chemical composition and repellency of essential oils from four Egyptian plants against Ixodes ricinus (L.) nymphs (Acari: Ixodidae). J Med Entomol 49:1067-1075

Elshamy AI, El Gendy A, Farrag AH, Nassar MI (2015) Antidiabetic and antioxidant activities of phenolic extracts of Conyza dioscoridis L. shoots. Int J Pharm Pharm Sci 7:65-72

Environmental Protection Agency (EPA) (2009) Pesticide products; registration application. Fed Regist 74:9396-9397

Feuerstein I, Muller D, Hobert K, Danin A, Segal R (1986) The constitution of essential oils from Artimisia herba alba populations of Israel and Sinai. Phytochemistry 25:2343-2347

Fleisher Z, Fleisher A, Nachbar RB (2002) Chemovariation of Artimisia herba alba Asso. aromatic plants of the Holy land and Sinai. J Essent Oil Res 14:156-160

Frances SP, Wirtz RA (2005) Repellents: past, present and future. J Am Mosq Control Assoc 21:1-3

Garboui SS, Jaenson TGT, Borg-Karlsson A-K, Pålsson K (2007) Repellency of methyl jasmonate to Ixodes ricinus nymphs (Acari: Ixodidae). Exp Appl Acarol 42:209-215

Gazim ZC, Rezende CM, Fraga SR, Svidzinski TI, Cortez DA (2008) Antifungal activity of the essential oil from Calendula officinals L. (Asteraceae) growing in Brazil. Braz J Microbiol 39:61-63

Grace MH (2002) Chemical composition and biological activity of the volatiles of Anthemis melampodina and Pluchea dioscoridis. Phytother Res 16:183-185

Habeeb SM (2010) Ethno-veterinary and medical knowledge of crude plant extracts and its methods of application (traditional and modern) for tick control. World Appl Sci J 11:1047-1054

Heylen D, Adriaensen F, Van Dongen S, Sprong H, Matthysen E (2013) Ecological factors that determine Ixodes ricinus tick burdens in the great tit (Parus major), an avian reservoir of Borrelia burgdorferi s.l. Int J Parasitol 43:603-611

Hussain AL, Anwar F, Sherazi STH, Przybylski R (2008) Chemical composition, antioxidant and antimicrobial activities of basil (Ocimum basilicum) essential oils depends on seasonal variations. Food Chem 108:986-995

Hvidstena D, Stordal F, Lager M, Rognerud B, Kristiansen B-E, Matussek A, Gray J, Stuen S (2015) Borrelia burgdorferi sensu lato-infected Ixodes ricinus collected from vegetation near the Arctic Circle. Tick Tick Borne Dis 6:768-773

Ibrahim MA, Kainulainen P, Aflatuni A, Tiilikkala K, Holopainen JK (2001) Insecticidal, repellent, antimicrobial activity and phytotoxicity of essential oils: with special reference to limonene and its suitability for control of insect pests. Agric Food Sci Finl 10:243-259

Iori A, Grazioli D, Gentile E, Marano G, Salvatore G (2005) Acaricidal properties of the essential oil of Melaleuca alternifolia Cheel (tea tree oil) against nymphs of Ixodes ricinus. Vet Parasitol 129:173-176

Jaenson TGT, Lindstrom A, Pålsson K (2003) Repellency of the mosquito repellent MyggA ${ }^{\circledR}{ }_{-}(N, N$ diethyl-3-methyl-benzamide) to the common tick Ixodes ricinus (L.) (Acari: Ixodidae) in the laboratory and field. Entomol Tidskr 124:245-251

Jaenson TGT, Pålsson K, Borg-Karlson A-K (2005) Evaluation of extracts and oils of tick-repellent plants from Sweden. Med Vet Entomol 19:345-352

Jaenson TGT, Garboui S, Pålsson K (2006) Repellency of oils of lemon eucalyptus, geranium, and lavender and the mosquito repellent MyggA natural to Ixodes ricinus (Acari: Ixodidae) in the laboratory and field. J Med Entomol 43:731-736

Jore S, Vanwambeke SO, Viljugrein H, Isaksen K, Kristoffersen AB, Woldehiwet Z, Johansen B, Brun E, Brun-Hansen H, Westermann S, Larsen I, Ytrehus B, Hofshagen M (2014) Climate and environmental change drives Ixodes ricinus geographical expansion at the northern range margin. Parasites Vectors 7:11-25

Kadri A, Chobba IB, Zarai Z, Békir A, Gharsallah N, Damak M, Gdoura R (2011) Chemical constituents and antioxidant activity of the essential oil from aerial parts of Artemisia herba alba grown in Tunisian semi-arid region. Afr J Biotechnol 10:2923-2929

Kim DH, Kim SI, Chang KS, Ahn YJ (2002) Repellent activity of constituents identified in Foeniculum vulgare fruit against Aedes aegypti (Diptera: Culicidae). J Agric Food Chem 50:6993-6996 
Maia C, Ferreira A, Nunes M, Vieira ML, Campino L, Cardoso L (2014) Molecular detection of bacterial and parasitic pathogens in hard ticks from Portugal. Tick Tick Borne Dis 5:409-414

Mohsen H, Ali F (2009) Essential oil composition of Artimisia herpa-alpa from Southern Tunisia. Molecules 14:1585-1594

Nassar M, Elshamy A, El Gendy AEN (2014) Phenolics, essential oil and biological activity of Conyza dioscoridis growing in Egypt. Planta Med 80:LP15

Nordlander G (1990) Limonene inhibits attraction to $\alpha$-pinene in the pine weevils Hylobius abietis and $H$. pinastri. J Chem Ecol 16:1307-1320

Okoh OO, Sadimenko AA, Afolayan AJ (2007) The effect of age on the yield and composition of the essential oils of Calendula officinalis. J Appl Sci 7:3806-3810

Okoh OO, Sadimenko AP, Asekun OT, Afolayan AJ (2008) The effects of drying on the chemical components of essential oils of Calendula officinalis L. Afr J Biotechnol 7:1500-1502

Omer MA, Johnson DA, Douhan LI, Hamm PB (2008) Detection, quantification and vegetative compatibility of Verticillium dahliae in potato and mint production soils in the Columbia Basin of Oregon and Washington. Plant Dis 92:1127-1131

Pettersson JH, Golovljova I, Vene S, Jaenson TGT (2014) Prevalence of tick-borne encephalitis virus in Ixodes ricinus ticks in Northern Europe with particular reference to Southern Sweden. Parasites Vectors 7:102-113

Salido S, Valenzuela LR, Altarejos J, Nogueras M, Sanchez A, Cano E (2004) Composition and infraspecific variability of Atrimisia helba alba from Southern Spain. Biochem Syst Ecol 32:265-277

Schlyter F, Smitt O, Sjödin K (2004) Carvone and less volatile analogues as repellent and deterrent antifeedants against the pine weevil, Hylobius abietis. J Appl Entomol 128:610-619

Schulz M, Mahling M, Pfister K (2014) Abundance and seasonal activity of questing Ixodes ricinus ticks in their natural habitats in Southern Germany in 2011. J Vector Ecol 39:56-65

Segal R, Eden L, Danin A, Kaiser M, Duddeck H (1985) Sesquiterpene lactones from Artimisia herba alba. Phytochemistry 24:1381-1382

Svehlova A, Berthova L, Sallay B, Boldis V, Sparagano OAE, Spitalska E (2014) Sympatric occurrence of Ixodes ricinus, Dermacentor reticulatus and Haemaphysalis concinna ticks and Rickettsia and Babesia species in Slovakia. Tick Tick Borne Dis 5:600-605

Tabanca N, Wang M, Avonto C, Chittiboyina AG, Parcher JF, Carroll JF, Kramer M, Khan IA (2013) Bioactivity-guided investigation of germanium essential oils as natural tick repellants. J Agric Food Chem 61:4101-4107

Thorsell W, Mikivera A, Tunón H (2006) Repelling properties of some plant materials on the tick Ixodes ricinus L. Phytomedicine 13:132-134

Verma RS, Rahman LU, Verma RK, Chauhan A, Singh A (2013) Essential oil composition of Pelargonium graveolens L'Her ex Ait cultivars harvested in different season. J Essent Oil Res 25:372-379

Zintl A, McGrath G, O'Grady L, Fanning J, Downing K, Roche D, Casey M, Gray JS (2014) Changing epidemiology of the tick-borne bovine parasite, Babesia divergens. Parasites Vectors 7:08. doi:10. 1186/1756-3305-7-S1-08 